\title{
Activation of the NF-kB pathway as a mechanism of alcohol enhanced progression and metastasis of human hepatocellular carcinoma
}

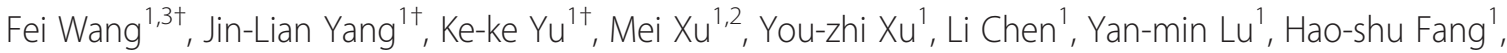 \\ Xin-yi Wang ${ }^{1,4}$, Zhong-qian Hu${ }^{1}$, Fei-fei Li ${ }^{1}$, Lixin Kan ${ }^{1}$, Jia Luo ${ }^{1,2^{*}}$ and Si-Ying Wang ${ }^{1 *}$
}

\begin{abstract}
Background: Hepatocellular carcinoma (HCC), the most common form of primary liver cancer, is the third leading cause of cancer-related death in human. Alcohol is a known risk factor for HCC. However it is still unclear whether and how alcohol enhances the progression and metastasis of existing HCC.

Methods and results: We first retrospectively investigated 52 HCC patients (24 alcohol-drinkers and 28 non-drinkers), and found a positive correlation between alcohol consumption and advanced Tumor-Node-Metastasis (TNM) stages, higher vessel invasion and poorer prognosis. In vitro and in vivo experiments further indicated that alcohol promoted the progression and migration/invasion of HCC. Specifically, in a 3-D tumor/endothelial co-culture system, we found that alcohol enhanced the migration/invasion of HepG2 cells and increased tumor angiogenesis. Consistently, higher expression of VEGF, MCP-1 and NF-KB was observed in HCC tissues of alcohol-drinkers. Alcohol induced the accumulation of intracellular reactive oxygen species (ROS) and the activation of NF-kB signaling in HepG2 cells. Conversely, blockage of alcohol-mediated ROS accumulation and NF-KB signaling inhibited alcohol-induced expression of VEGF and MCP-1, the tumor growth, angiogenesis and metastasis.

Conclusion: This study suggested that chronic moderate alcohol consumption may promote the progression and metastasis of HCC; the oncogenic effect may be at least partially mediated by the ROS accumulation and NF-kB-dependent VEGF and MCP-1 up-regulation.
\end{abstract}

Keywords: Alcohol, Angiogenesis, Human hepatocellular cancer, Metastasis, Reactive oxygen species

\section{Background}

Hepatocellular carcinoma (HCC) is the most common primary liver cancer and accounts for up to $70-85 \%$ of primary liver cancers [1]. Advanced HCC carries a poor prognosis with a five-year survival rate $<10 \%$ [2]. It is well recognized that both genetic and environmental factors contribute to human HCC. Alcohol, an important environmental factor, was classified as a group I carcinogen and chronic alcohol consumption has been recognized as an important risk factor for liver cancers [3,4]. In addition

\footnotetext{
*Correspondence: Jialuo888@uky.edu; sywang@ahmu.edu.cn

${ }^{\dagger}$ Equal contributors

'Department of Pathophysiology, School of Basic Medical Science, Anhui Medical University, 81 MeiShan Road, Hefei, Anhui 230032, P.R. China 2 Department of Pharmacology and Nutritional Sciences, University of Kentucky College of Medicine, Lexington, Kentucky 40536, USA Full list of author information is available at the end of the article
}

to act as risk factor for carcinogenesis, epidemiological studies also indicated that alcohol consumption is often associated with advanced and aggressive tumors [5]. Although alcohol is clearly recognized as a risk factor for liver cancers, its role in cancer progression and metastasis is currently unknown. We specifically hypothesized that chronic alcohol consumption might enhance HCC progression and metastasis.

Tumor angiogenesis, the formation of new blood vessels from endothelial precursors within tumors, is a prerequisite step for growth and progression of solid malignancies [6]. Vascular endothelial growth factor (VEGF) is an essential player in tumor angiogenesis and mediates tumor aggressiveness [7-9]. Monocyte chemotactic protein-1 (MCP-1), a key CC chemokine responsible for trafficking and activation of monocytes/macrophages has been

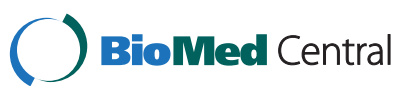

(c) 2015 Wang et al.; licensee BioMed Central. This is an Open Access article distributed under the terms of the Creative Commons Attribution License (http://creativecommons.org/licenses/by/4.0), which permits unrestricted use, distribution, and reproduction in any medium, provided the original work is properly credited. The Creative Commons Public Domain Dedication waiver (http://creativecommons.org/publicdomain/zero/1.0/) applies to the data made available in this article, unless otherwise stated. 
recognized as an important angiogenic chemokine [10,11]; it also plays a critical role in solid tumors [12]. Previous studies indicated that alcohol exposure up-regulated the expression of VEGF and MCP-1 in other experimental models [13]. It has also been reported that the expression of VEGF and MCP-1 was regulated by reactive oxygen species and NF-kB $[14,15]$. Based on these findings, we further hypothesized that chronic alcohol consumption might enhance $\mathrm{HCC}$ progression and metastasis through up-regulating the expression of VEGF/MCP-1, which, in turn, may be regulated by reactive oxygen species and the NF-кB signaling pathway. We tested this hypothesis by retrospectively analyzing clinical data, and functional analysis using experimental models.

\section{Results}

Alcohol consumption is associated with advanced TNM stages, greater vessel invasion and poorer prognosis

We retrospectively surveyed $52 \mathrm{HCC}$ patients, among which 24 patients consumed alcohol during last 10-40 years and 28 patients were no-drinkers. No statistical differences were found in the age, hepatitis B virus (HBV) infection, presence of cirrhosis, liver function (Child grade), tumor size, or number of tumors between the alcoholic and nonalcoholic patients $(P>0.05)$, except for gender $(P=0.026$; Table 1). We categorized the alcohol drinkers into two groups, i.e., low (<35 g/day) and moderate-heavy consumption (35-87.5 g/day and $\geq 87.5 \mathrm{~g} /$ day) based on the average number of drinks they stated. We calculated the amount of ethanol ingested by assuming $35 \mathrm{~g}$ of ethanol

Table 1 Univariate analysis of tumor characteristics and alcohol consumption in the $\mathbf{5 2}$ HCC patients

\begin{tabular}{|c|c|c|c|c|c|}
\hline \multirow[t]{2}{*}{ Variables } & & \multirow[t]{2}{*}{ Never } & \multicolumn{3}{|c|}{ Alcohol consumption $\mathrm{n}(\%)$} \\
\hline & & & Ever & $x^{2}$ & $P$ value \\
\hline \multirow[t]{2}{*}{ Sex } & Male & $21(46.7)$ & $24(53.3)$ & 4.953 & $0.026^{a}$ \\
\hline & Female & $7(100)$ & $0(0)$ & & \\
\hline \multirow[t]{2}{*}{ Age(yr) } & $\leq 50$ & 19(59.4) & 13(40.6) & 1.023 & 0.312 \\
\hline & $>50$ & $9(45)$ & $11(55)$ & & \\
\hline \multirow[t]{2}{*}{ HBV infection } & Negative & $4(45.4)$ & $5(55.6)$ & 0.065 & 0.799 \\
\hline & Positive & $24(55.8)$ & $19(44.2)$ & & \\
\hline \multirow[t]{2}{*}{ Cirrhosis } & Negative & $7(53.8)$ & $6(46.2)$ & 0.000 & 1.000 \\
\hline & Positive & $21(53.8)$ & $18(46.2)$ & & \\
\hline \multirow[t]{3}{*}{ Child grade } & $A$ & $26(54.2)$ & $22(45.8)$ & - & $0.505^{*}$ \\
\hline & B & $1(33.3)$ & $2(66.7)$ & & \\
\hline & C & $1(100)$ & $0(0)$ & & \\
\hline \multirow[t]{2}{*}{ Tumor size(cm) } & $\leq 5$ & $15(51.7)$ & $14(48.3)$ & 0.119 & 0.730 \\
\hline & $>5$ & $13(56.5)$ & $10(43.5)$ & & \\
\hline \multirow[t]{2}{*}{ Number of tumors } & 1 & $27(55.1)$ & $22(44.9)$ & 0.119 & 0.730 \\
\hline & $\geq 2$ & $1(33.3)$ & $2(66.7)$ & & \\
\hline
\end{tabular}

${ }^{\mathrm{a} P}<0.05 ;{ }^{*}$ exact $P$. per $100 \mathrm{ml}$ of about $43 \% \mathrm{v} / \mathrm{v}$ spirits. We used the TumorNode-Metastasis (TNM) of International Union Against Cancer (UICC) system to further classify the stages of the HCC. Specifically, UICC TNM is comprised of 4 stages (I, II, III, IV) based on growth pattern (single or multiple), size $(\leq 5 \mathrm{~cm}$ or $>5 \mathrm{~cm})$, vascular invasion, and extrahepatic spread. We further analyzed the effects of alcohol intake on tumor progression and examined the relationship between the amount alcohol consumption and the extent of tumor progression. According to the multivariate binary logistic regression analysis adjusted for sex, age, HBV infection and liver function (Child grade), the moderate and high drinkers(35-87.5 g/day and $\geq 87.5 \mathrm{~g} /$ day) had a significantly higher percentage of advanced tumors (TNM stage III-IV) (OR =22.99; 95\% CI: 2.13-248.91; $P=0.010)$, and higher vessel invasion $(\mathrm{OR}=21.04 ;$ 95\% CI: 1.61-275.56, $P=0.020)$ (Table 2). There was no significant correlation with tumor differentiation (data not shown). However, patients with low alcohol consumption (<35 g/day) and nondrinkers did not display statistical difference in TNM stage and vessel invasion.

To further clarify this issue, we included more eligible HCC patients for the evaluation of correlation between alcohol consumption and the prognosis. Eighty-two HCC patients, including 52 cases in first cohort which were confirmed by post-operative pathology from 2006 to 2009, were followed-up for 70 months. Clinical characteristics of the 82 HCC patients were summarized in Table 3 . Forty of them were nondrinkers and forty two are alcohol users. At the end of the following-up, 42 patients died. Three alcoholic and 2 nonalcoholic patients died of liver failure after surgery. Twenty-four alcoholic and 13 nonalcoholic patients die due to tumor recurrence and metastasis. According to the multivariate Cox regression analysis, the TNM stage, liver function (Child grade $\mathrm{C}$ ) and alcohol consumption were identified as independent prognostic factors for death due to HCC recurrence. It also showed that the hazard ratio of alcoholic versus nonalcoholic patients was 4.576 (95\% CI: 1.854-11.293, $P<0.01$ ) (Table 4). The overall survival rates for nondrinking $\mathrm{HCC}$ patients at 12 and 36 months were $75 \%$ and $62.5 \%$ respectively; however, the same rates for alcohol drinking HCC patients were $57.15 \%$ and $35.7 \%$ respectively. The mortality at 70 months in alcoholic patients was significantly higher than that of nonalcoholic patients [64.3\% (27/42) vs 37.5\% (15/40), $P=0.015]$. Alcohol consumption significantly shorted life span of patients $(P=0.021)$ (Figure 1$)$. Thus, HCC patients who were alcohol drinkers were associated with advanced TNM stages, higher vessel invasion and poorer prognosis.

\section{Alcohol consumption is associated with enhanced angiogenesis in $\mathrm{HCC}$ tissues}

To understand the underlying mechanisms, we first sought to determine whether alcohol consumption affected tumor 
Table 2 Odds ratios of TNM stage and vessel invasiveness in relation to different levels of alcohol consumption

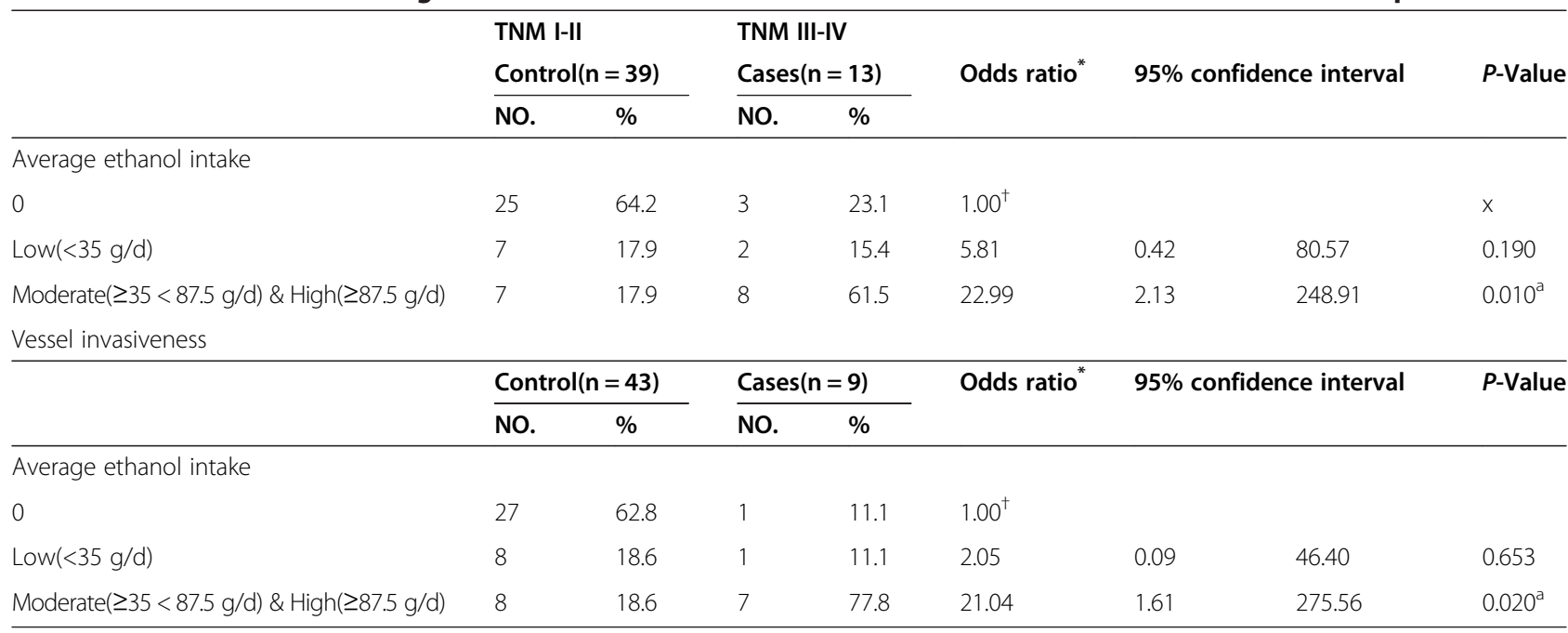

${ }^{\circ}$ Adjusted for sex, age, HBV infection and liver function (Child grade).

${ }^{\dagger}$ Reference category.

${ }^{\mathrm{a}} P<0.05$.

angiogenesis. We compared average micrcovessel density (AMVD) in liver cirrhosis tissue, distant non-cancerous tissues, HCC tissues of nondrinkers and alcohol users. As showed in Figure 2A and B, AMVD in HCC tissue was higher than liver cirrhosis tissue and distant non-cancerous

Table 3 Major clinical characteristics of the 82 HCC patients

\begin{tabular}{|c|c|c|}
\hline Covariate & & All cases $(n=82)$ \\
\hline \multirow[t]{2}{*}{ Sex } & Male, n (\%) & $67(81.7)$ \\
\hline & Female & $15(18.3)$ \\
\hline Age (yr) & Mean \pm SD & $50.9 \pm 13.1$ \\
\hline \multirow[t]{2}{*}{ Alcohol history } & Never, n (\%) & $40(48.8)$ \\
\hline & Ever & $42(51.2)$ \\
\hline \multirow[t]{2}{*}{ HBV infection } & Negative, n (\%) & $11(13.4)$ \\
\hline & Positive & $71(86.6)$ \\
\hline Maximal tumor size $(\mathrm{cm})$ & Mean $\pm S D$ & $6.33 \pm 4.03$ \\
\hline \multirow[t]{3}{*}{ Tumor grade } & Well differentiated, n (\%) & $18(22.0)$ \\
\hline & Moderately differentiated & $51(62.2)$ \\
\hline & Poorly differentiated & 13(15.9) \\
\hline \multirow[t]{2}{*}{ TNM stage } & I-II, n (\%) & $50(61.0)$ \\
\hline & III-IV & $32(39.0)$ \\
\hline \multirow[t]{2}{*}{ Vessel invasiveness } & Negative, n (\%) & $64(78.0)$ \\
\hline & Positive & $18(22.0)$ \\
\hline \multirow[t]{3}{*}{ Child grade } & A, n (\%) & $64(78.0)$ \\
\hline & B & $14(17.1)$ \\
\hline & C & $4(4.9)$ \\
\hline \multirow[t]{2}{*}{ Cirrhosis } & Negative, n (\%) & $21(25.6)$ \\
\hline & Positive & $61(74.4)$ \\
\hline
\end{tabular}

tissues, indicating higher angiogenesis in tumor $(42.6 \pm 4.82$ vs $27.2 \pm 1.48$ and $42.6 \pm 4.82$ vs $16.2 \pm 4.43, P<0.01)$. More importantly, AMVD in HCC tissues of alcohol users was significantly higher than that of nondrinkers.

\section{Alcohol consumption is associated with higher expression} of VEGF, MCP-1 and NF-KB in HCC tissues

To further understand the molecular mechanisms, we examined the expression of VEGF, MCP-1 and NF- $\mathrm{kB}$ in $\mathrm{HCC}$ tissues of nondrinkers and alcohol users. As shown in Figure 2C, VEGF and MCP-1 were expressed in tumor and hepatic cells. MCP-1 was also present in interstitial monocytes cells. Higher expression of VEGF and MCP-1 was observed in HCC tissues compared to cirrhosis and distant non-cancerous liver tissues (Figure 2D). Moreover, minimum NF-kB was mainly observed in the cytoplasm

Table 4 Cox regression analysis of risk factors for death due to recurrence in 82 HCC patients

\begin{tabular}{|c|c|c|c|c|}
\hline Variables & HR & $95 \%$ & ence interval & $P$-value \\
\hline$\overline{\text { Sex }}$ & 2.469 & 0.850 & 7.173 & 0.097 \\
\hline Age & 0.863 & 0.430 & 1.732 & 0.679 \\
\hline HBV infection & 0.665 & 0.250 & 1.767 & 0.413 \\
\hline TNM stage & 4.089 & 1.864 & 8.972 & $0.000^{b}$ \\
\hline Liver function(Child grade) A & & 0.038 & & \\
\hline B & 2.092 & 0.846 & 5.174 & 0.110 \\
\hline C & 4.185 & 1.162 & 15.074 & $0.029^{\mathrm{a}}$ \\
\hline Alcohol consumption & 4.576 & 1.854 & 11.293 & $0.001^{b}$ \\
\hline
\end{tabular}




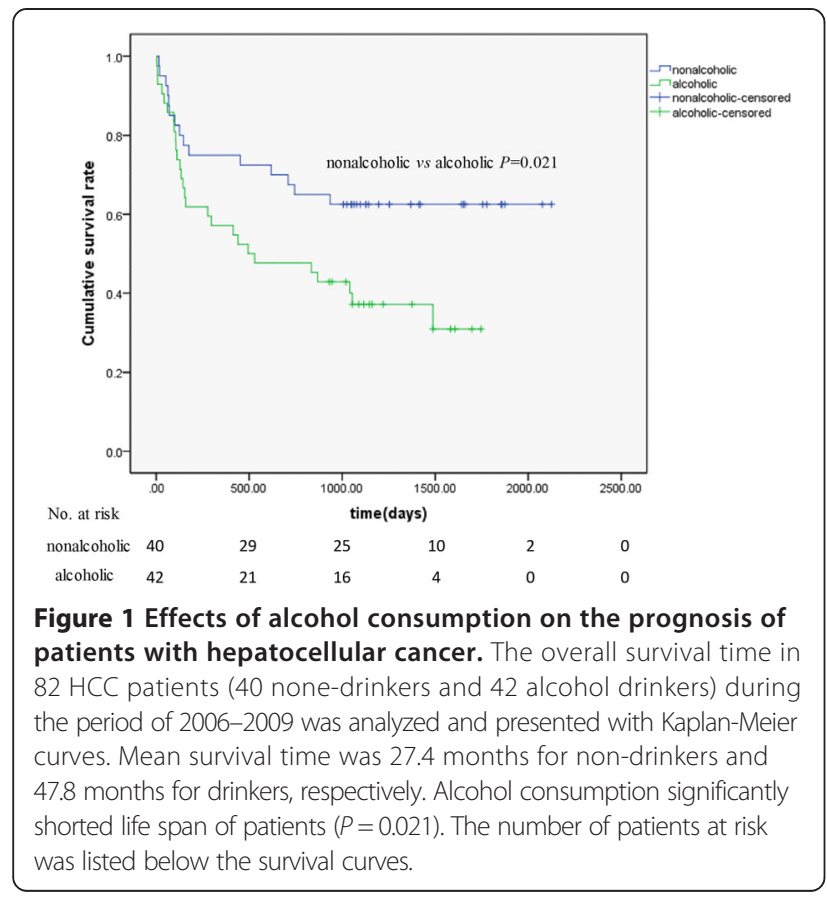

of hepatocytes in cirrhosis and distant non-cancerous liver tissues (Figure $2 \mathrm{C}$ and $\mathrm{E}$ ), while in HCC tissues, strong expression was mainly located in the cytoplasm and nucleus of cancer cells. In all cases, the intensity for VEGF, MCP-1 and NF- $\mathrm{kB}$ immunostaining in the HCC tissues of alcohol users was much stronger than that of nondrinkers, even though tissues staining of drinkers and nondrinkers within the same TNM stage were compared.

\section{Involvement of reactive oxygen species (ROS) and NF-KB in ethanol-stimulated migration/invasion and tumor angiogenesis of HepG2 cells}

The clinical data from human studies indicated a positive association between alcohol consumption and enhanced progression and metastasis of HCC. We therefore sought to determine the causal relationship in experimental models. We first evaluated the effects of ethanol on the migration/invasion of human hepatocarcinoma HepG2 cells. Cell migration was evaluated by wound healing assay and cell invasion was determined with a Matrigel Boyden Chamber Assay. As shown in Figure 3A and B, ethanol exposure (0.2\%) significantly increased the migration/ invasion of HepG2 cells. The Matrigel assay indicated that ethanol exposure increased the invasion of HepG2 cells (Figure $3 \mathrm{C}$ and $\mathrm{D},{ }^{*} P<0.05$, ** $P<0.01$ ).

We next used a 3D co-culture model to evaluate tumor angiogenesis. In this system, human umbilical vein endothelial cells (HUVEC) attached to Cytodex beads are able to form a 3D capillary tube-like network (sprouts), indicative of angiogenesis. As shown in Figure 4A-C, the beads with sprouts were $36.4 \%$ in HUVEC alone group and
48.7\% in HUVEC co-cultured with HepG2 cells. Ethanol exposure $(0.2 \%)$ significantly increased the percentage of beads with sprouts (61.1\%) in HUVEC/ HepG2 cell coculture. These results indicated that ethanol stimulated tumor angiogenesis. The effects of ethanol were inhibited by PDTC or C3G. PDTC is a known NF-kB inhibitor and a metal chelator with some antioxidant property, while C3G inhibits ROS and mitigate ethanol-induced oxidative stress. However, the MTT assay showed that C3G and PDTC $(20 \mu \mathrm{M})$ did not affect the proliferation of HepG2 cells (data not shown). To test the involvement of ROS and NF- $\mathrm{kB}$ signaling in this process, we demonstrated that ethanol induced intracellular ROS accumulation and C3G and PDTC inhibited ethanol-stimulated ROS production in HepG2 cells (Figure 5A and B). Since NF- $\mathrm{kB}$ is also an important redox-sensitive transcription factor and ethanol increased intracellular ROS level, we postulated that ethanol might activate NF- $\mathrm{B}$ signaling. In the canonical

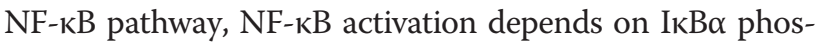
phorylation and degradation. We thus examined the effect of ethanol on the expression of active $\mathrm{p} 65 \mathrm{NF}-\mathrm{kB}$ protein in HepG2 cells. As show in Figure 5C-5E, ethanol reduced cytoplasmic p65 NF- $\mathrm{B}$ while increased nuclear p65 $\mathrm{NF}-\mathrm{kB}$, indicating that ethanol stimulated nuclear translocation of p65 NF-кB. Ethanol also enhanced ІкB- $\alpha$ phosphorylation and decreased the levels of IkB- $\alpha$. These results indicated that ethanol exposure activated NF- $\mathrm{kB}$ signaling. Consistently, PDTC reduced IKB $\alpha$ phosphorylation and $\mathrm{p} 65 \mathrm{NF}-\mathrm{kB}$ nuclear translocation, while increased levels of IкB- $\alpha$. Similarly, C3G also abolished ethanol-induced activation NF- $\mathrm{kB}$, suggesting that ethanol-activated NF- $\mathrm{kB}$ signaling was mediated by ROS.

We further examined the effects of ethanol on the transcription of NF- $\mathrm{KB}$ using a luciferase reporter. As shown in Figure 5E, ethanol increased NF- $k B$ transcriptional activity, while C3G or PDTC inhibited ethanol-stimulated NF- $\mathrm{kB}$ transcriptional activity. Taken together, ethanol may stimulate the NF- $\mathrm{kB}$ pathway by inducing ROS production, which in turn increases migration/invasion and tumor angiogenesis.

\section{Alcohol enhances liver tumor growth and aggressiveness in mice}

We sought to further confirm our findings in a mouse xenograft model in which HepG2 cells were implanted subcutaneously in nude mice. As shown in Figure 6A-C, ethanol exposure significantly enhanced the rate of tumor growth; the size/weight of tumor in ethanol-exposed mice was significantly larger than that in control groups. Ethanol exposure also significantly increased tumor metastasis (Figure 6D), angiogenesis (Figure 6E) and the expression of VEGF and MCP-1 (Figure 6G).

In addition, PDTC treatment significantly inhibited ethanol stimulation of tumor growth and metastasis in 


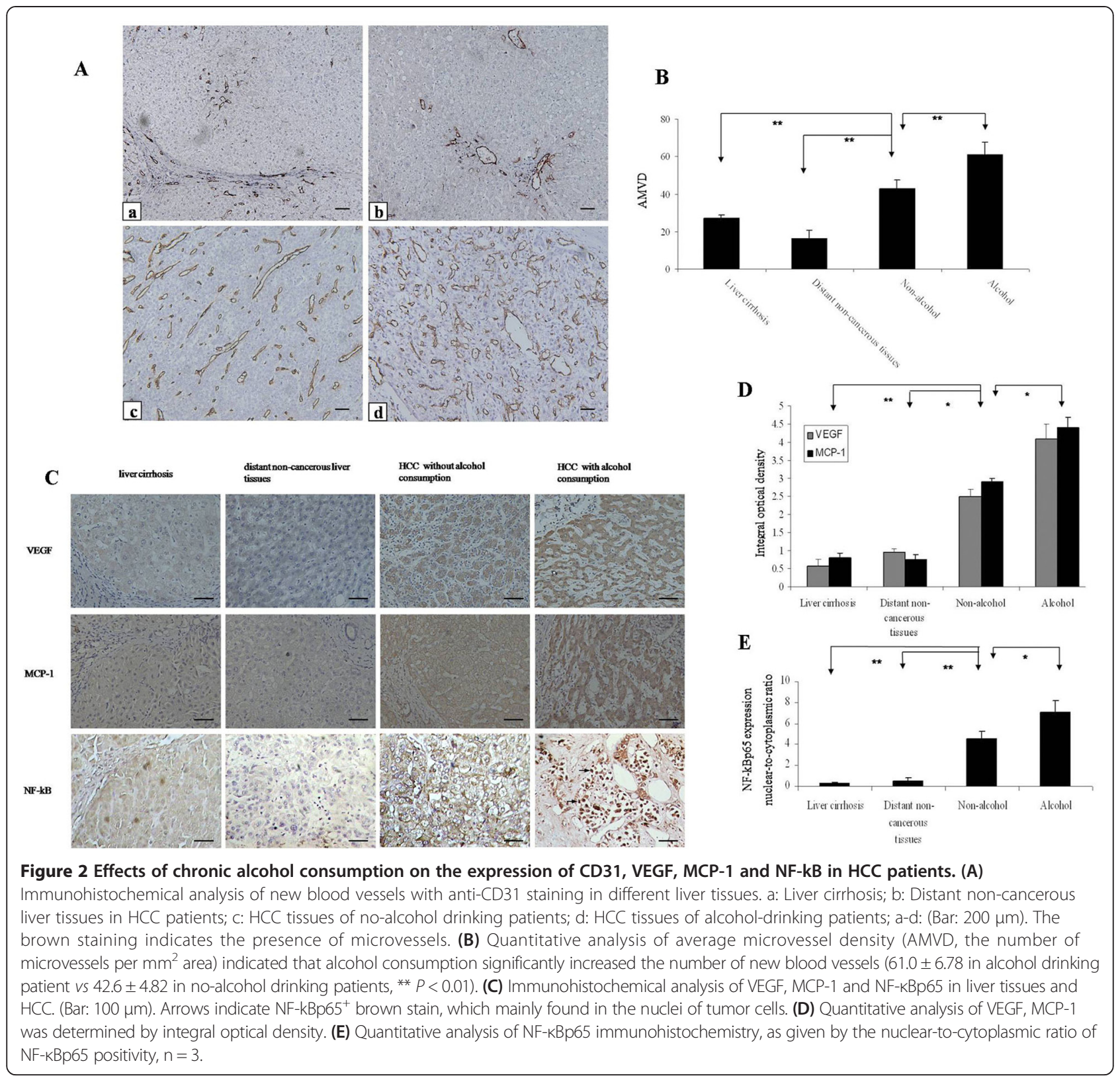

mice (Figure 6A-D). Consistent with the observation made in the in vitro model, PDTC inhibited ethanolpromoted angiogenesis (Figure 6E and F). PDTC also reduced the basal expression VEGF and MCP-1 and blocked ethanol-induced increase in VEGF and MCP-1 expression in liver tumors (Figure 6G).

\section{Discussion}

The association between alcohol consumption and the risk of HCC has been well-established. For example, a study with a cohort of 19,000 drinkers confirmed that alcohol enhances the risk of upper gastrointestinal tumors including liver cancer [16]. Rehm et al. [17] reported that RRs of liver cancer for low $(0-39.99 \mathrm{~g} / \mathrm{d})$, hazardous
(40-59.99 g/d) and harmful (60+ g/d) levels of alcohol consumption compared to never drinkers are 1.45, 3.03, and 3.60 respectively. Hennig et al. suggested the close association between alcohol consumption and HCC progression in vitro [18]. Huang et al. also confirmed that ethanol consumption induces hepatocellular carcinoma cell metastasis by changing the extracellular matrix in vitro and this ability was reduced by food components such as pterostilbene and curcumin analogues [19]. In a mouse model of hepatocaricinogenesis, Brandon-Warner et al. found that chronic ethanol feeding accelerated hepatocellular carcinoma progression in male mice [20]. In our study, we demonstrate a positive correlation between alcohol consumption and enhanced HCC progression, even 


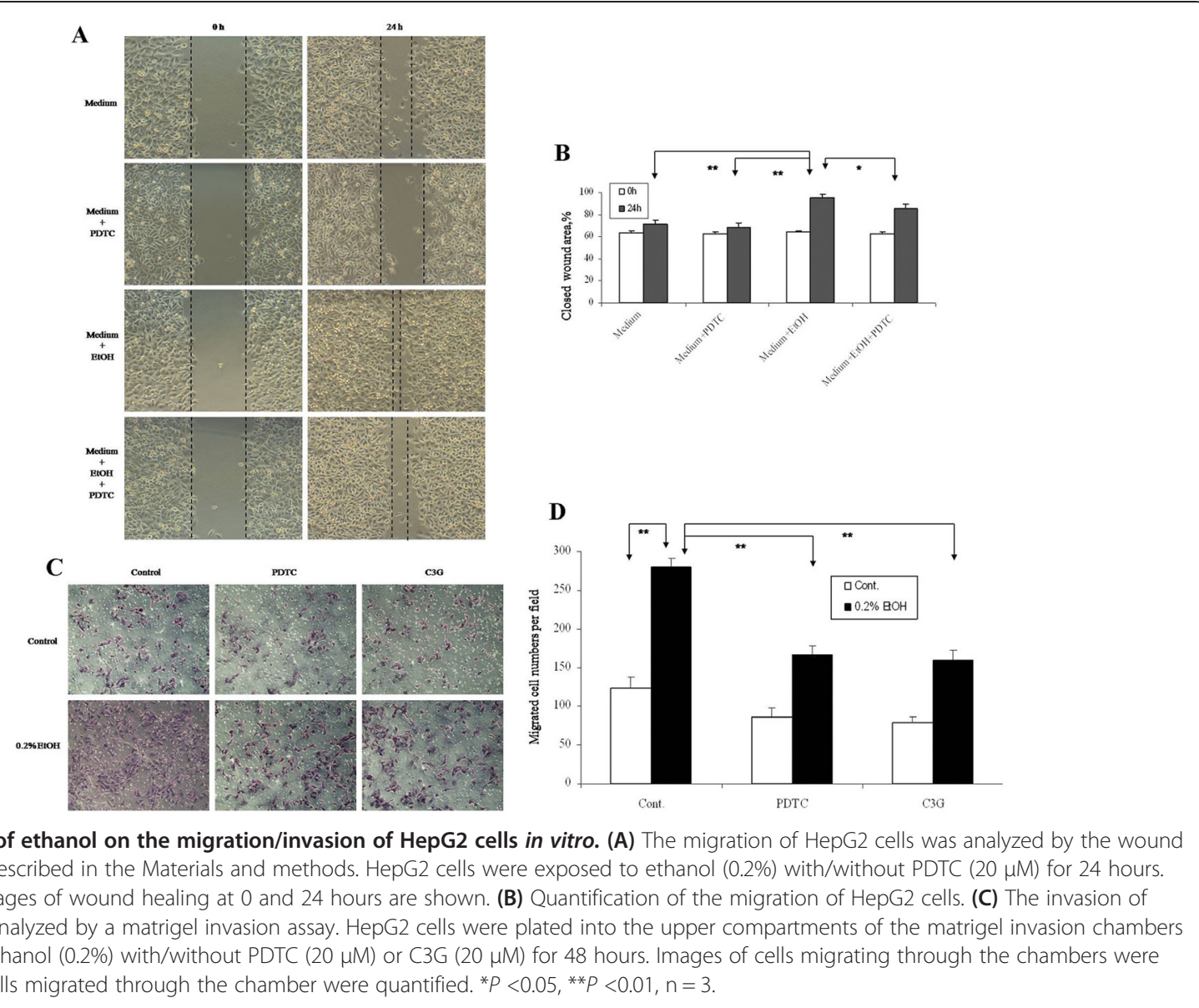

though the cohort of this study is relatively small (82 patients). Donato et al. showed that heavy alcohol consumption (>80 $\mathrm{g}$ of ethanol per day) is associated with the increased risk of HCC compared to non-drinkers [21]. However, our data indicated that the moderate and heavy drinking (35-87.5 g/day and $\geq 87.5 \mathrm{~g} /$ day) was associated with enhanced HCC progression. There are many factors underlying this discrepancy. A larger cohort may be needed to provide more definite conclusion. In our cohort, the number of male patients is much larger than that of female; this is consistent with the epidemiological findings that males are about two to four times more likely to develop HCC than females [22]. In future study, analysis of a larger cohort may be necessary to evaluate the interaction between alcohol consumption and other risk factors, such as Hepatitis B virus or hepatitis $C$ virus which are known risk factors for the development of liver cancer due to chronic liver inflammation [23]. Nevertheless, our clinical data provides the necessary foundation for our further experimental studies.

$\mathrm{HCC}$ is a vascular-dependent malignant tumor; an increase in tumor dimension above $0.5 \mathrm{~mm}$ will induce the proliferation of vascular endothelial cells and angiogenesis which is essential for tumor growth and metastatic dissemination [24]. Our previous study and results from others showed that alcohol may promote tumor angiogenesis in animals $[13,25,26]$. The current study for the first time demonstrates that alcohol consumption is closely associated with a higher micrcovessel density in HCC tissues, which implied that alcohol potentially enhances tumor angiogenesis in $\mathrm{HCC}$ patients. This interpretation is further supported by experimental data. For example, alcohol increases micrcovessel density in tumor tissues in a HCC xenograft model . Furthermore, we show that alcohol can stimulate tumor angiogenesis in a $3 \mathrm{D}$ model of tumor/endothelial cell co-culture system. Together, these results indicate that enhanced angiogenesis is a potential mechanism for alcohol-promoted progression of HCC.

VEGF and MCP-1 are key mediators for tumor angiogenesis and metastasis [27,28]. VEGF, as a pro-angiogenic factor, plays an essential role in the process of angiogenesis, including microvascular permeability, endothelial cell proliferation and tumor cell migration [29,30]. VEGFpositive tumors in HCC patients had much greater invasive potential and intrahepatic metastasis than VEGF-negative tumors [31]. Tan et al. [25] showed that alcohol increased 


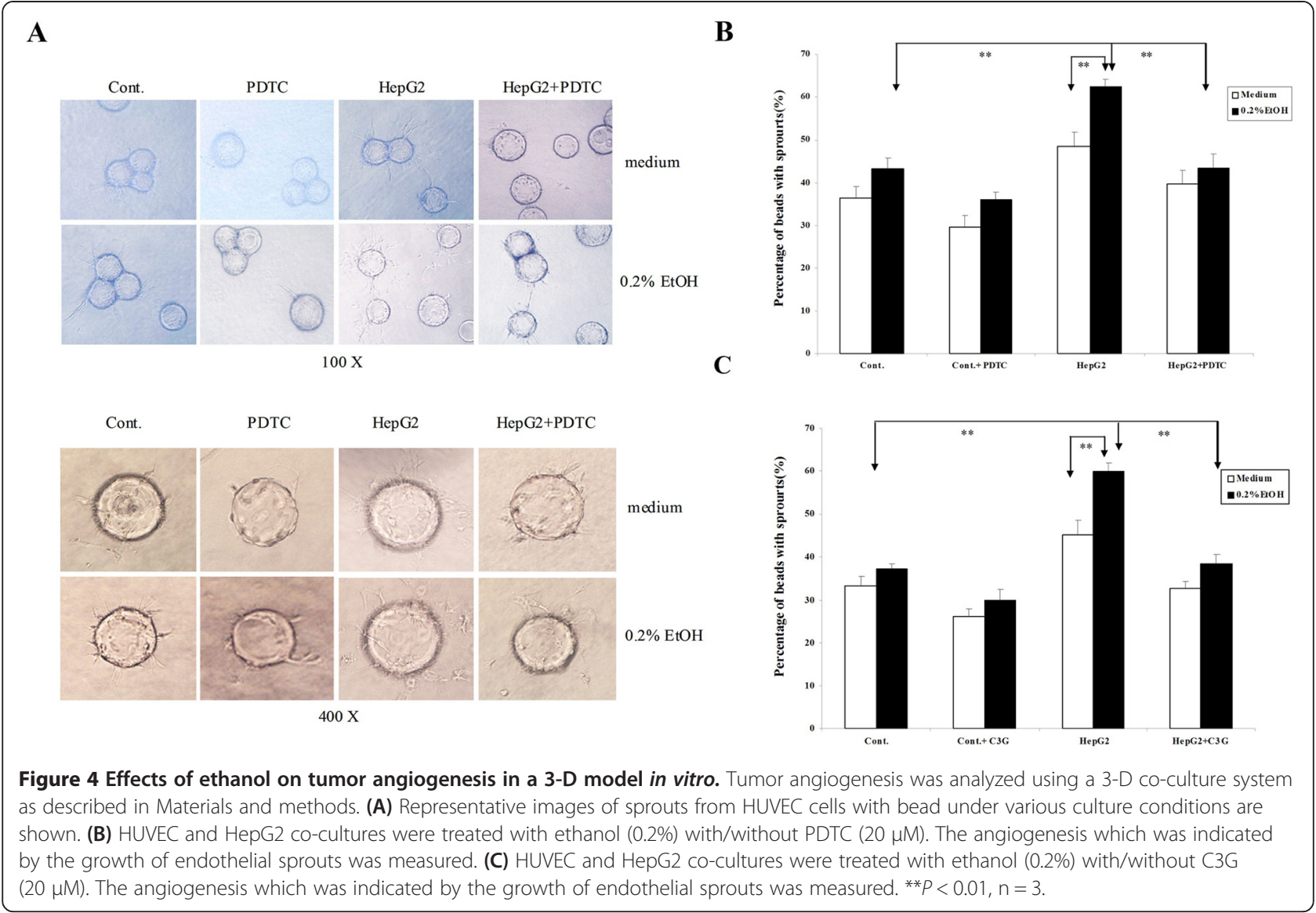

the expression of VEGF in melanoma xenograft model. MCP-1 is also a potent pro-angiogenic chemokine which is associated with many malignant tumors progression by recruitment of macrophages and induction of angiogenesis [32,33]. In both ectopic and orthotropic xenograft models, the MVD was significantly increased in tumors over-expressing MCP-1 [34]. We have previously demonstrated that alcohol can stimulate the expression of MCP1 in breast cancer cells, which caused an enhanced angiogenesis [13]. That a higher expression level of VEGF and MCP-1 is observed in HCC patients of alcohol-drinkers supports a role of VEGF and MCP-1 in alcohol promotion of HCC.

$\mathrm{NF}-\mathrm{kB}$ plays a key role in tumorigenesis/progression and also regulates the expression of VEGF and MCP-1 [35]. Consistently, we show that the expression of NF- $\mathrm{kB}$ is higher in alcohol-drinkers HCC patients than in that in non-drinkers. Furthermore, PDTC, an inhibitor of NF- $\mathrm{KB}$ and an antioxidant, attenuates alcohol-induced VEGF and MCP-1 expression in mice, supporting that ethanol-stimulated expression of VEGF/MCP-1 is mediated by NF- $\mathrm{kB}$ signaling.

$\mathrm{NF}-\mathrm{KB}$ activity is regulated by reactive oxygen species (ROS) [36]. We have previously shown that ethanol can induce intracellular ROS accumulation in breast cancer cells $[37,38]$. ROS plays an important role in carcinogenesis as a result of oxidative stress including oxidative injury, inflammation, and lipid peroxidation [39]. C3G, a potent antioxidant, has been shown to effectively inhibit ROS and mitigate ethanol-induced oxidative stress [38]. We confirm here that ethanol causes the accumulation of intracellular ROS in HepG2 cells and C3G scavenges ethanol-induced ROS. More importantly, C3G blocks ethanol-stimulated NF- $\mathrm{kB}$ promoter activities, suggesting that ethanol-induced ROS mediated NF- $\mathrm{kB}$ transcriptional activity. At cellular level, both PDTC and C3G effectively inhibit ethanol-induced migration/invasion of HepG2 cells and abolish the pro-angiogenic effect of ethanol in a 3-D model of tumor/endothelial cell co-culture. They also attenuate ethanol-induced tumor growth and metastasis in mice.

\section{Conclusions}

In conclusion, our results indicate that alcohol consumption induces intracellular ROS accumulation which results in the activation of NF- $\mathrm{kB}$ and up-regulation of VEGF and MCP-1. VEGF and MCP-1 promotes tumor angiogenesis which may mediate ethanol-stimulated progression/metastasis of HCC (Figure 7). 


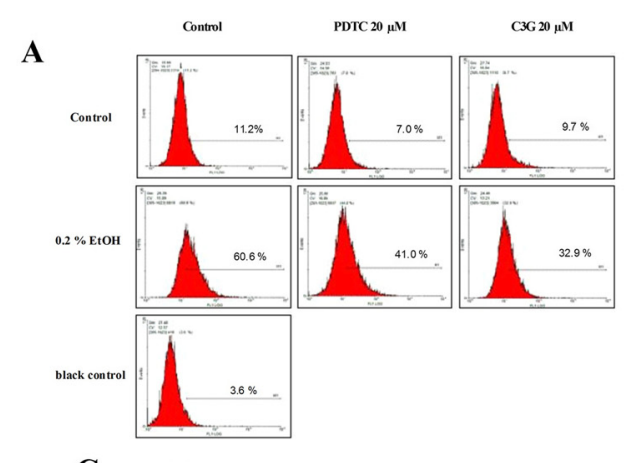

$\mathbf{B}$

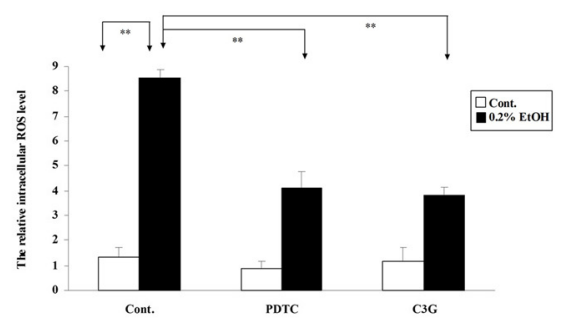

C
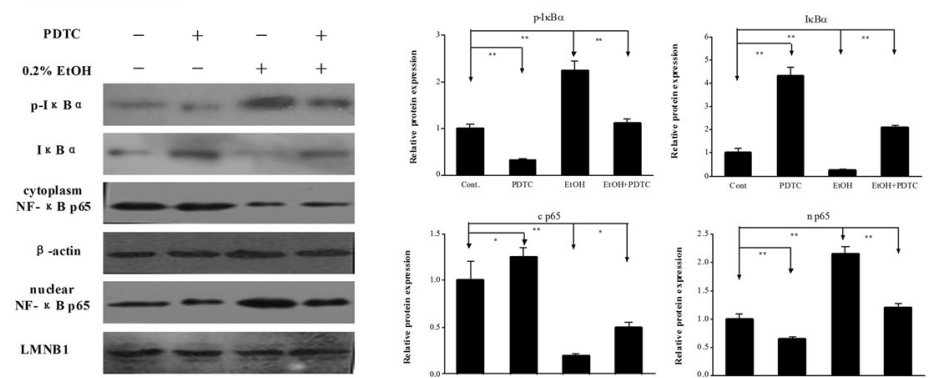

D
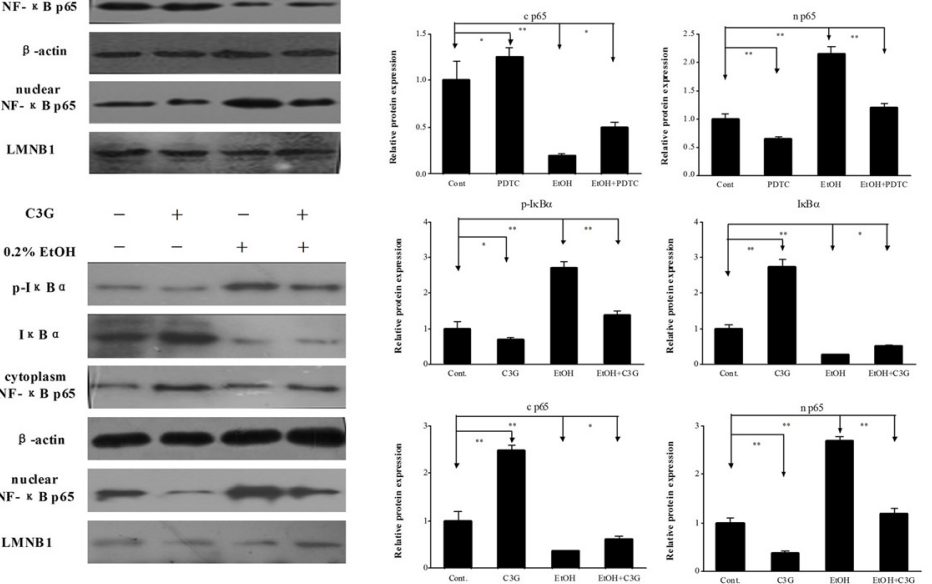

$\mathbf{E}$

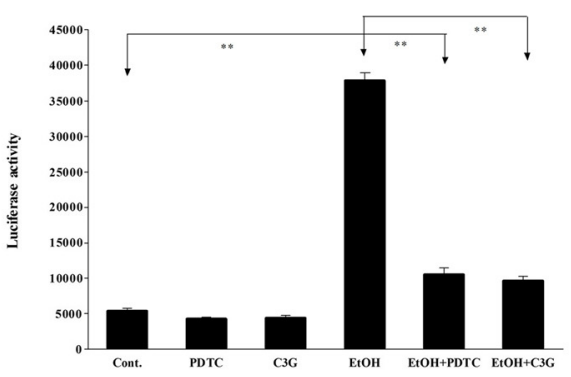

Figure 5 Effects of ethanol on intracellular ROS and the activation of NF-kB. (A) HepG2 cells were treated with ethanol (0.2\%) with/without PTDC or C3G for 0.5 hours. Intracellular ROS was detected by flow cytometry as described in Materials and methods. (B) The relative levels of intracellular ROS were quantified. ${ }^{*} P<0.01$. (C-D) HepG2 cells were treated with ethanol (0.2\%) with/without PTDC or C3G for 2 hours. Expression of IkBa, p- $\mathrm{kBa}$ and NF-kB p65 in cytoplasm and nuclei was analyzed by immunoblotting (left panel). The relative expression levels were quantified with a densitometry (right panel). ${ }^{*} P<0.05$, ${ }^{* *} P<0.01$. (E) NF-kB activity was detected by the luciferase reporter gene assay. ${ }^{* *} P<0.01, \mathrm{n}=3$.

\section{Materials and methods}

\section{Drugs and reagents}

Ethanol, fibrinogen, aprotinin, thrombin and Pyrrolidine dithiocarbamate (PDTC) were purchased from Sigma Chemical Co. (St. Louis, MO). Cyanidin-3-glucoside (C3G) was prepared as previously described [38]. AntiMCP1 and anti-VEGF antibodies were obtained from Abcam (Cambridge, MA). Anti-NF-кB p65, ІкB $\alpha$, p-ІкB $\alpha$ and anti-LMNB1 antibodies were purchased from Protein Tech Group (Chicago, IL, USA). Anti- $\beta$-actin was obtained from Cell signaling Technology (Danvers, MA). Anti-CD31 antibody was obtained from BD Pharmingen (San Diego, CA). Reactive oxygen species detection reagents were obtained from Invitrogen Molecular Probes (Eugene, OR). MTT assay kit was purchased from Roche Molecular Biochemicals (Indianapolis, 

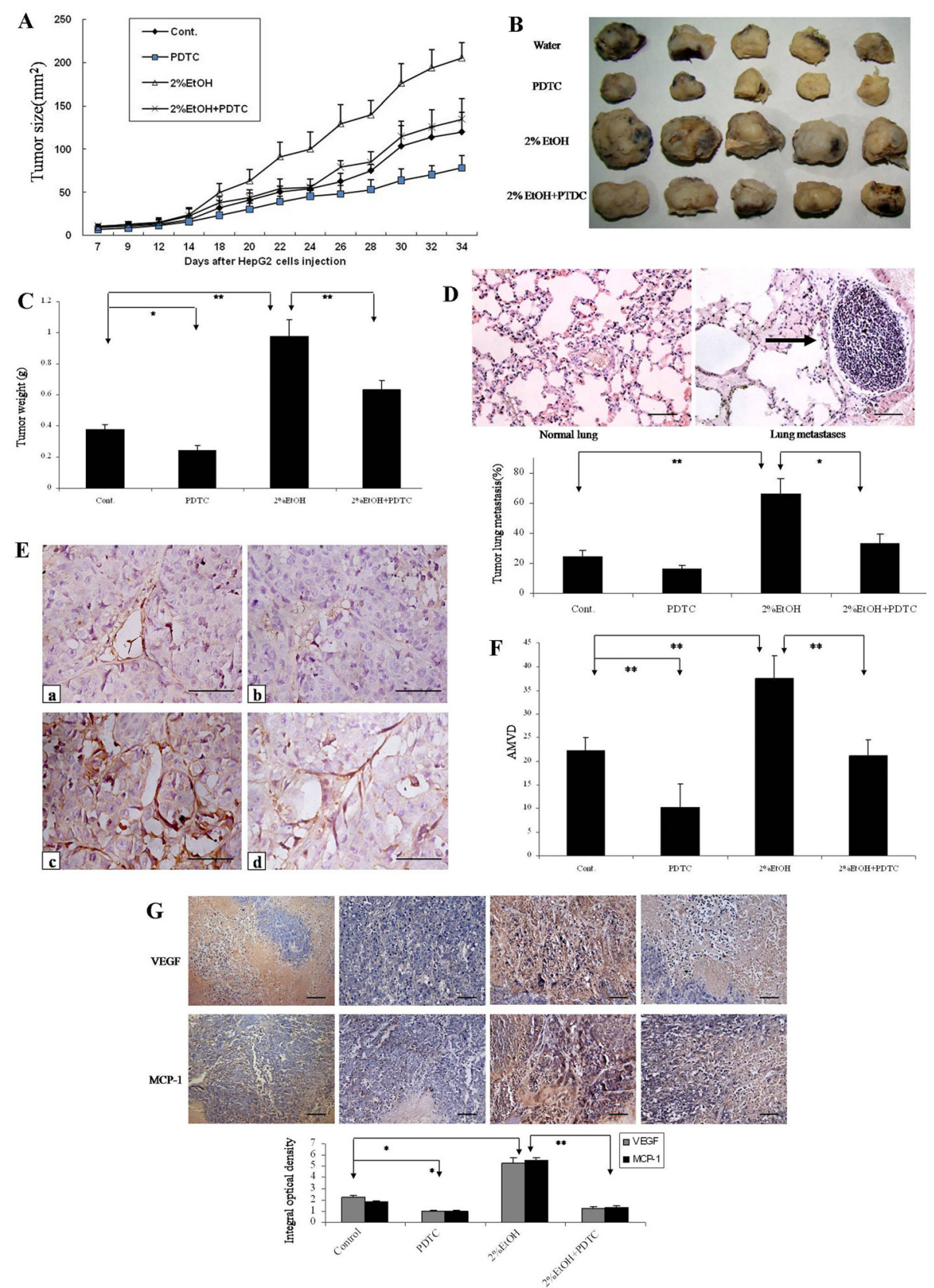

Figure 6 Effects of ethanol on tumor development in a xenograft model. (A) HepG2 cells were implanted subcutaneously in nude mice. The mice were exposed to ethanol in drinking water ( 0 or $2 \%$ ethanol). Mice were injected with PDTC ( 0 or $100 \mathrm{mg} / \mathrm{kg}$ ). The size of tumor was measured every other day. (B) At the end of experiments, tumors were removed for subsequent analyses. A representative image shows tumors from control and ethanol-exposed mice with/without PDTC treatment. (C) Tumor weight was determined and presented as the means \pm SD $(n=12)$. (D) Tumor metastases in the lungs were analyzed. A representative microphotograph shows metastatic carcinoma nodes in the lungs of ethanol-exposed mice (arrow, top panel; Bar: $100 \mu \mathrm{m}$ ). The percentage of mice which were positive for lung metastasis was quantified (bottom panel). (E) Microvessels in tumor tissues were detected by CD31 immunohistochemistry (Bar: $50 \mu \mathrm{m})$. a: water control, b: water plus PDTC, C: 2\% ethanol, d: 2\% ethanol plus PDTC. (F) AVMD was determined as described in Figure 2. (G) VEGF and MCP-1 in tumor tissues were detected by IHC (Bar: $100 \mu \mathrm{m}) .{ }^{*} P<0.05,{ }^{* *} P<0.01, \mathrm{n}=3$.

IN). Matrigel Invasion Chambers were purchased from BD Biosciences (Bedford, MA). Cytodex 3 beads were purchased from Amersham Pharmacia Biotech (Piscataway, NJ).

\section{Clinical patient data}

The medical records of $52 \mathrm{HCC}$ patients, admitted to first hospital of Anhui Medical University, were retrospectively analyzed between January and December 2009 


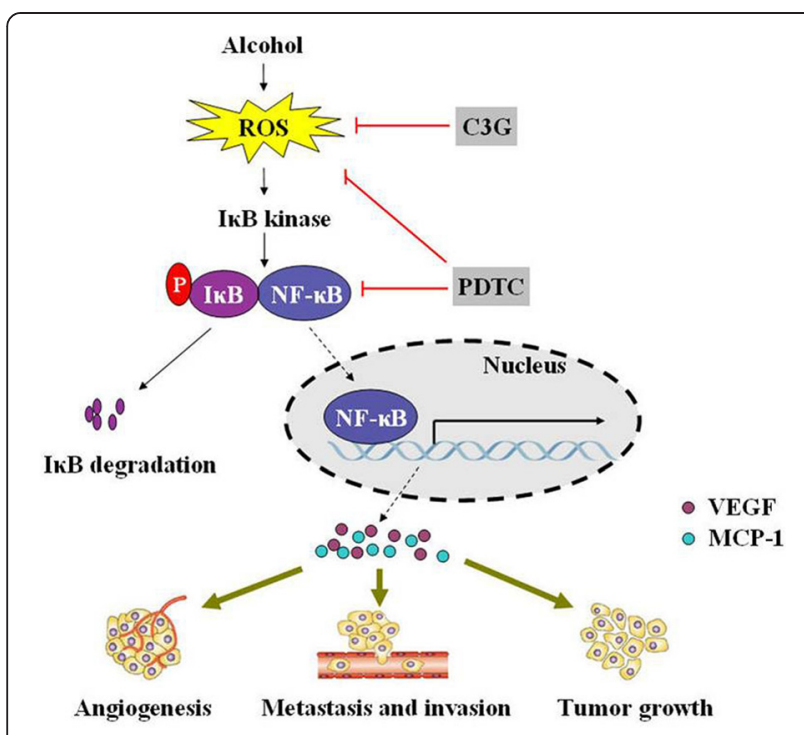

Figure 7 Proposed working model for the role of the NF-kB signaling pathway in the regulation of ethanol-enhanced the progression of HCC. (1) ROS induced by alcohol mediated activation of the NF-kB pathway. This effect can be abolished by C3G or PDTC. (2) Nuclear translocation of NF-kB via phosphorylation by the IkB kinase, which then binds target DNA that regulates VEGF and MCP-1 gene expression. Ultimately, the changes stimulated by alcohol enhance angiogenesis, tumor growth and metastasis.

(Table 1). Patients were asymptomatic at admission and diagnosed by examining the liver with computed tomography. All patients were performed anatomical liver resection. HCC and cirrhosis was confirmed by pathology. Cirrhosis developed in $76.9 \%$ (39 of 52) of patients. Forty-three patients $(82.7 \%)$ were infected with hepatitis $B$ virus. A series of demographic and clinical data were collected including alcohol consumption, tumor characteristics and pathologic stages. Survival and follow-up data were acquired by telephone interviews. With the approval of the first affiliated hospital of Anhui Medical University of Human Studies Committee, formalin-fixed paraffin-embedded tumor materials of $52 \mathrm{HCC}$ patients were obtained. The histological sections of all cases were evaluated by oncopathologists.

\section{Cell culture and ethanol exposure}

Human hepatoma cell line HepG2 and mouse embryonic fibroblast cell line NIH3T3 were provided by the Institute of Cell and Biochemistry, Chinese Academy of Sciences (Shanghai, China) and maintained in Dulbecco's modified Eagle's medium(DMEM) containing 10\% fetal bovine serum (FBS), penicillin $(100 \mathrm{U} / \mathrm{ml}) /$ streptomycin $(100 \mathrm{U} / \mathrm{ml})$, at $37^{\circ} \mathrm{C}$ with $5 \% \mathrm{CO} 2$. The original primary human umbilical vein endothelial cells (HUVECs) were isolated from human umbilical veins by using collagenase (Roche Diagnostics, Switzerland) as previously described [40], and maintained on $0.2 \%$ gelatin coated in
EGM-2 medium (Lonza, Walkersville, MD, USA) which consists of endothelial cell basal medium (EBM-2) with $10 \%$ FBS and other additives. Alcohol was added to the medium at concentrations of $0.2 \% \mathrm{v} / \mathrm{v}$ ethanol. Cell culture plates were placed on a rack inside a plastic container sealed with a tight-fitting lid. At the bottom of each container, there was a 200-ml water bath, which contained the same concentration of ethanol as in the cultural media. The containers were placed in a humidified environment and maintained at $37^{\circ} \mathrm{C}$ with $5 \% \mathrm{CO} 2$.

\section{Animals and ethanol administration}

Male nude mice (4-5 weeks old, $15-20$ g, $\mathrm{n}=12$ /group) were purchased from the Animal Center, Chinese Academy of Sciences. The ethanol was administrated in drinking water as described previously [13]. Briefly, mice were given $2 \%$ ethanol in drinking water for a $12 \mathrm{~h}$ period during the night and then replaced with water without ethanol at day time. The mice in the control group were provided with regular drinking water only. All procedures were carried out according to the guidelines of the Animal Welfare Act approved by the Institutional Animal Care and Use Committee of Anhui Medical University. The blood ethanol concentration (BEC) was determined at 6:00 a.m. using an Analox AM1 Alcohol Analyzer (Analox Instruments, Lunenburg, MA) as previously described [41]. The BEC was $56.18 \pm 11.6 \mathrm{mg} / \mathrm{dl}$.

\section{Mouse model of tumor xenograft}

HepG2 human hepatoma cells were implanted subcutaneously in nude mice according to the previous study [13]. Briefly, three days after ethanol exposure, HepG2 cells $\left(1 \times 10^{6}\right.$ in $\left.100 \mu \mathrm{l} \mathrm{PBS}\right)$ were injected subcutaneously into mice using a 23-gauge needle. The mice were continually provided with $2 \%$ ethanol in drinking water or regular drinking water without ethanol. The size of the tumors was monitored every 2 days; two perpendicular dimensions of tumors were measured with a dial caliper. The volume was calculated based on the formula: $\mathrm{V}=0.25 \mathrm{a} \times$ $\mathrm{b}^{2}$; $\mathrm{a}$ is the longest and $\mathrm{b}$ is the shortest dimension. At the end of experiment, animals were killed and the tumors were removed. Some of the tumor tissues were fixed with $10 \%$ neutral formalin for and immunohistochemical studies. To evaluate the effect of PDTC on ethanol-mediated tumor growth, PDTC [100 mg/kg in $100 \mu \mathrm{l}$ of Dimethyl sulfoxide (DMSO)] or DMSO alone was injected intraperitoneally 2 days following ethanol exposure. PDTC was administered every three days. The dosage of PDTC was selected based on previous studies [42]. There were seven mice for each treatment group.

\section{Histology and immunohistochemistry}

Immunohistochemical (IHC) procedure was performed generally as described [43]. Briefly, Five-micrometer-thick 
sections were cut and deparaffinaged in xylene prior to rehydration using gradient alcohol. For antigen retrieval, sections were treated with citrate buffer saline $(\mathrm{pH}$ 6.0) for 15 minutes at $95^{\circ} \mathrm{C}$ in a microwave oven. After blocking with $10 \%$ normal goat serum for 30 minutes at room temperature, the sections were incubated with primary antibodies: anti-MCP-1 (1:100), anti-VEGF (1:150), antiNF-kBp65 (1:100), or anti-CD31 (1:100) overnight at $4^{\circ} \mathrm{C}$. Following incubation, sections were washed with phosphate buffered solution and incubated with horseradish peroxidase-conjugated goat anti-rabbit IgG for $1 \mathrm{~h}$ at room temperature. The avidin-biotin complex was added and the enzyme activity was visualized with 3, 3'-diaminobenzidine $(\mathrm{DAB})$. Negative controls were prepared using PBS instead of the primary antibody. The average microvessel density (AMVD) of ten selected microscopic fields was calculated and expressed as the number of microvessels per $\mathrm{mm}^{2}$ area, according to previous report [44]. The integral optical density (IOD) of the stained sections was measured with a computer-assisted image-processing and analytical system. NF-kBp65 expression was analyzed by counting NF-кBp65-positive hepatocytes within $50 \mathrm{HPF}$ with discrimination of the intracellular distribution serving as an indicator of NF-kB nuclear translocation. The nuclear-to-cytoplasmic ratio was calculated by dividing the number of cells with nuclear NF- $\mathrm{kBp} 65$ positivity by the number of cytoplasmic NF-kBp65 positive cells.

\section{Analysis of experimental lung metastasis}

After 5 weeks of ethanol exposure, mice in four groups ( $\mathrm{n}=22$ for each group) were sacrificed. The fresh lung samples were harvested and fixed with $10 \%$ formalin for histopathology analysis. Tissues were paraffin-embedded and sectioned at a thickness of $5 \mu \mathrm{m}$. The sections were stained with hematoxylin-eosin (H\&E) and then examined under the microscope to evaluate the morphological changes of metastasis tumors.

\section{Detection of intracellular reactive oxygen species}

Intracellular reactive oxygen species (ROS) levels were measured using the fluorescent dye CM-H2DCFDA (Invitrogen Corporation, Carlsbad, CA) as previously described [45]. Briefly, HepG2 cells were trypsinized and seeded onto 6-well plates pretreated with/without C3G $(20 \mu \mathrm{M})$ or PDTC $(20 \mu \mathrm{M})$ for 0.5 hours before ethanol exposure. After the treatment, cells were washed with cold PBS and incubated with $5 \mu \mathrm{M}$ CM-H2DCFDA for $30 \mathrm{~min}$, followed by several additional washes with cold PBS. Cells were trypsinized and transferred into polystyrene round-bottom tubes; intracellular ROS levels were measured with a flow cytometer (FACScalibur, BD Biosciences, San Jose, CA) at an emission wavelength of $525 \mathrm{~nm}$.

\section{Preparation of protein extracts}

Cells $\left(5 \times 10^{6}\right)$ were harvested, resuspended in $50 \mu \mathrm{l}$ of lysis buffer A $(10 \mathrm{mM}$ Hepes, $10 \mathrm{mM} \mathrm{KCl}, 0.1 \mathrm{mM}$ $\mathrm{MgCl} 2$, $0.1 \mathrm{mM}$ EDTA, $2 \mu \mathrm{g} / \mathrm{ml}$ leupeptin, $2 \mu \mathrm{g} / \mathrm{ml}$ pepstatin, $0.5 \mathrm{mM}$ PMSF, $\mathrm{pH}$ 7.9), incubated on ice for $10 \mathrm{~min}$ and centrifuged for $10 \mathrm{~min}$ at $800 \times \mathrm{g}$ at $4^{\circ} \mathrm{C}$. The supernatant was treated as the cytoplasmic fraction. The pellet (nuclei) was washed with buffer $\mathrm{A}$ and nuclear proteins were extracted in presence of $50 \mu \mathrm{l}$ of buffer B (10 mM Hepes, $400 \mathrm{mM} \mathrm{NaCl}, 1.5 \mathrm{mM} \mathrm{MgCl}$, $0.1 \mathrm{mM}$ EDTA, $2 \mu \mathrm{g} / \mathrm{ml}$ leupeptin, $2 \mu \mathrm{g} / \mathrm{ml}$ pepstatin, 0.5 mM PMSF, pH 7.9). Protein concentration was determined using a BCA protein assay kit (Pierce, Rockford, IL) according to the manufacturer's instructions.

\section{Western blotting analysis}

SDS-PAGE and Western blotting were performed according to standard procedures. Briefly, protein samples $(10 \mu \mathrm{g})$ were subjected to electrophoresis on $4-12 \%$ SDS-polyacrylamide gradient gels and transferred to a PVDF membrane. After overnight blocking with 2\% BSA in TBS-Tween $0.1 \%$, the membranes were probed

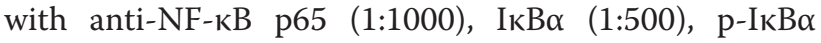
(1:1000), $\beta$-actin (1:1000) or anti-LMNB1 (1:1000) antibodies overnight at $4^{\circ} \mathrm{C}$. Anti-rabbit HPR conjugated antibody was used as a secondary antibody followed by enhanced chemiluminescence reaction. All Western blotting were repeated three times.

\section{Luciferase reporter gene assay}

NIH3T3 cells were trypsinized and seeded in 96-well plates at an initial density of $2 \times 10^{4}$ cells/well in DMEM containing $10 \% \mathrm{FBS}$ at $37^{\circ} \mathrm{C}$ with $5 \% \mathrm{CO} 2$ overnight. The cells at $50 \%-80 \%$ confluence were performed with $6 \mu \mathrm{g}$ of pGL4.32 [luc2P/NF-kB-RE/Hygro] plasmid (Promega) transfected with Lipofectamine ${ }^{\mathrm{Tu}} 2000$ Transfection Reagent (Invitrogen) for normalizing transfection efficiency. The non-transfected cells were used as blank group. At 48 hours after transfection, cells were collected and resuspended in passive lysis buffer (Promega). Then the cells were exposed with/without ethanol in the presence or absence of PDTC or C3G. After incubation for $2 \mathrm{~h}$, Luciferase activity was evaluated with a dual luciferase assay system (GloMax 96 Microplate Luminometer, Promega) according to manufacturers.

\section{Cell proliferation assay}

The MTT assay was employed to determine the number of viable cells in culture. Briefly, the cells were plated into 96-well plates and exposed to ethanol with/without C3G $(20 \mu \mathrm{M})$ or PDTC $(20 \mu \mathrm{M})$ for indicated times. After the treatment, $10 \mu \mathrm{l}$ of MTT reagent was added into each well and the plates were incubated at $37^{\circ} \mathrm{C}$ for $4 \mathrm{~h}$. After lightly vortexing the plate on an orbital shaker, 
the spectrophotometric absorbance was read on a microplate reader (Bio Rad Model 3550-UV) at $595 \mathrm{~nm}$. Each individual experiment was performed at least three times.

\section{Wound healing migration assay}

Wound healing assay was carried out to determine the cell migration ability of tumor cells. The wound healing migration assay was performed as described previously [46]. Briefly, HepG2 cells were plated on 6-well plates and grown to $80 \%$ - $90 \%$ confluence. Sterilized one-milliliter pipette tip was used to generate a wound across the cell monolayer, and the plates were washed with PBS. The cells were then treated with ethanol $(0.2 \% \mathrm{v} / \mathrm{v})$ in the presence or absence of PDTC $(20 \mu \mathrm{M})$ for $24 \mathrm{~h}$. Cells migrated into the wounded area or protruded from the border of the wound were visualized and photographed under the inverted microscope (Olympus, Japan).

\section{Cell invasion assay}

Cell invasion was performed in BD Bio Coat Matrigel Invasion chambers (BD Biosciences, Clontech; Bedford, MA, USA) with a porous polycarbonate membrane (8.0 micron pore size) as previously described [47]. Briefly, HepG2 cells $\left(5 \times 10^{5}\right)$ were seeded onto upper chambers and treated with ethanol in the presence or absence of C3G or PDTC $(20 \mu \mathrm{M})$. The lower compartment of the chamber was filled with medium containing $2 \% \mathrm{BSA}$ served as chemoattractants for the cells. The chambers were cultured at $37^{\circ} \mathrm{C}$ in $5 \% \mathrm{CO} 2$ for $48 \mathrm{~h}$ to allow tumor cell invasion through the matrix. Migrated cells were fixed with $100 \%$ methanol and stained with Giemsa for invasion assay. The filters were photographed and the cells were counted. The invasion assay was repeated in five separate experiments, with control and experimental groups performed in parallel.

\section{Three-dimensional (3D) endothelial cell and tumor co-culture system}

3-D model of endothelial cell and tumor cell co-culture system was performed to investigate the effect of ethanol on tumor angiogenesis as described previously [13]. In this model, endothelial cells were induced to form a 3D capillary tube-like network on a fibrin gel bead system in the presence or absence of tumor cells. In brief, HUVEC or HepG2 cells $\left(1 \times 10^{6}\right)$ were trypsinized and mixed with Cytodex beads $\left(3 \times 10^{3}\right)$ in DMEM medium. After incubation, the mixtures of cells/Cytodex beads were resuspended in medium containing $2.5 \mathrm{mg} / \mathrm{ml}$ fibrinogen and $0.15 \mathrm{U} / \mathrm{ml}$ aprotinin. A volume of $0.5 \mathrm{ml}$ fibrinogen/ bead solution was added to 24-well cell culture plates that were pre-coated with $0.625 \mathrm{U}$ of thrombin. After coagulation, the resulting fibrin gels contained endothelial cells (HUVEC or HepG2) adhering to the beads. For co-culture of endothelial cells/tumor cells, the medium collected from HepG2 cells with/without ethanol in presence or absence of C3G or PDTC were added on top of the fibrin gels. The culture media was changed every two days. At different time points, cell morphogenesis was observed using an inverted phase-contrast microscope. Tube formation was quantified by counting branches from four representative fields per replicate. These experiments were performed in triplicate.

\section{Statistical analysis}

Data were presented as means \pm standard deviations and analyzed by ANOVA, followed by Student-Newman-Keuls test. The correlations between alcohol consumption and clinicopathological features were analyzed by Pearson Chi-square test. Multivariable binary logistic regression was carried out to estimate odds ratio (OR) with its 95\% confidence intervals $(\mathrm{CI})$ in order to assess the risk factors for HCC aggressiveness. The multivariate Cox proportional hazards regression model was employed to estimate the prognostic factors associated with HCC recurrence. For the survival analysis after surgical resection, the data were processed using the Kaplan-Meier method and were compared using the log-rank test. Statistical analysis was conducted with SPSS 16.0 (IBM Corporation, Chicago, IL, United States). A value of $P<0.05$ was considered statistically significant.

\section{Abbreviations}

HCC: Hepatocellular carcinoma; HepG2: Human hepatoma cell line; PDTC: Pyrrolidine dithiocarbamate; C3G: Cyanidin-3-glucoside; IHC: Immunohistochemistry; VEGF: Vascular endothelial growth factor MCP-1, Monocyte chemotactic protein-1; ROS: Reactive oxygen species; NF-kB: Nuclear factor kappa B; IkBa: Inhibitor of NF-kB; p- IkBa: Phosphorylation of IkBa; TNM: Classification of malignant tumours; HUVECs: Human umbilical vein endothelial cells; NIH3T3: Mouse embryonic fibroblast cell line; BEC: Blood ethanol concentration; AMVD: Average microvessel density; OR: Odds ratio; RRs: Relative risks; Cl: Confidence interval; H\&E: Hematoxylin-eosin.

\section{Competing interests}

The authors declare that they have no competing interests.

\section{Authors' contributions}

FW, J-LY, K-KY, S-YW carried out the molecular studies, participated in the sequence alignment and drafted the manuscript; Y-ZX, MX, LC, F-FL, carried out the in vivo experiments; Y-ML, H-SF, X-YW and Z-QH participated in the in vitro experiments; JL, SYW participated in the design of the study and performed the statistical analysis; $J$, J-LY, K-KY, Y-ZX and LK conceived of the study, and participated in its design and coordination and helped to draft the manuscript. All authors read and approved the final manuscript.

\section{Acknowledgements}

This work was supported by grants from the Project of the National Natural Sciences Foundation of China (81272258) and Natural Science Foundation of Anhui Province (1308085MH121). JL is also supported by grants from $\mathrm{NIH}$ (AA015407 and AA017226).

\section{Author details}

'Department of Pathophysiology, School of Basic Medical Science, Anhui Medical University, 81 MeiShan Road, Hefei, Anhui 230032, P.R. China. ${ }^{2}$ Department of Pharmacology and Nutritional Sciences, University of Kentucky College of Medicine, Lexington, Kentucky 40536, USA. ${ }^{3}$ Department of Burns, The First Affiliated Hospital of Anhui Medical University, Hefei, 
Anhui 230022, P.R. China. ${ }^{4}$ Department of Clinical Medicine, Anhui Medical University, Hefei, Anhui 230032, P.R. China.

Received: 2 April 2014 Accepted: 22 December 2014 Published online: 27 January 2015

\section{References}

1. Mittal S, El-Serag HB. Epidemiology of hepatocellular carcinoma: consider the population. J Clin Gastroenterol. 2013;47(Suppl):S2-6.

2. Gluer AM, Cocco N, Laurence JM, Johnston ES, Hollands MJ, Pleass HC, et al. Systematic review of actual 10-year survival following resection for hepatocellular carcinoma. HPB (Oxford). 2012;14(5):285-90.

3. Venook AP, Papandreou C, Furuse J, de Guevara LL. The incidence and epidemiology of hepatocellular carcinoma: a global and regional perspective. Oncologist. 2010;15 Suppl 4:5-13.

4. McKillop $\mathbb{H}$, Schrum LW. Role of alcohol in liver carcinogenesis. Semin Liver Dis. 2009;29(2):222-32.

5. Severi T, van Malenstein $H$, Verslype C, van Pelt JF. Tumor initiation and progression in hepatocellular carcinoma: risk factors, classification, and therapeutic targets. Acta Pharmacol Sin. 2010;31(11):1409-20.

6. Lubek JE, Clayman L. An update on squamous carcinoma of the oral cavity, oropharynx, and maxillary sinus. Oral Maxillofac Surg Clin North Am. 2012;24 (2):307-16.

7. Yancopoulos GD, Davis S, Gale NW, Rudge JS, Wiegand SJ, Holash J. Vascular-specific growth factors and blood vessel formation. Nature. 2000:407(6801):242-8.

8. Hicklin DJ, Ellis LM. Role of the vascular endothelial growth factor pathway in tumor growth and angiogenesis. J Clin Oncol. 2005;23(5):1011-27.

9. Tsai MS, Chang CC, Kuo ML, Wu YT. Vascular endothelial growth factor-A and changes in a tumor-bearing mouse model with Lewis lung cancer. Oncol Lett. 2011;2(6):1143-7.

10. Martinez CO, McHale MJ, Wells JT, Ochoa O, Michalek JE, McManus LM, et al. Regulation of skeletal muscle regeneration by CCR2-activating chemokines is directly related to macrophage recruitment. Am J Physiol Regul Integr Comp Physiol. 2010;299(3):R832-42.

11. Niu J, Kolattukudy PE. Role of MCP-1 in cardiovascular disease: molecular mechanisms and clinical implications. Clin Sci (Lond). 2009;117(3):95-109.

12. Vázquez-Lavista LG, Lima G, Gabilondo F, Llorente L. Genetic association of monocyte chemoattractant protein 1 (MCP-1)-2518 polymorphism in Mexican patients with transitional cell carcinoma of the bladder. Urology. 2009;74(2):414-8.

13. Wang S, Xu M, Li F, Wang X, Bower KA, Frank JA, et al. Ethanol promotes mammary tumor growth and angiogenesis: the involvement of chemoattractant factor MCP-1. Breast Cancer Res Treat. 2012;133(3):1037-48.

14. Moon DO, Kim MO, Kang SH, Choi YH, Kim GY. Sulforaphane suppresses TNF-alpha-mediated activation of NF-kappaB and induces apoptosis through activation of reactive oxygen species-dependent caspase-3. Cancer Lett. 2009;274(1):132-42.

15. Shimizu H, Bolati D, Higashiyama Y, Nishijima F, Shimizu K, Niwa T. Indoxyl sulfate upregulates renal expression of MCP-1 via production of ROS and activation of NF-KB, p53, ERK, and JNK in proximal tubular cells. Life Sci. 2012;90(13-14):525-30

16. Thygesen LC, Mikkelsen P, Andersen TV, Tønnesen H, Juel K, Becker U, et al. Cancer incidence among patients with alcohol use disorders long-term follow-up. Alcohol Alcohol. 2009;44(4):387-91.

17. Rehm J, Baliunas D, Borges GL, Graham K, Irving H, Kehoe T, et al. The relation between different dimensions of alcohol consumption and burden of disease: an overview. Addiction. 2010;105(5):817-43.

18. Hennig M, Yip-Schneider MT, Klein P, Wentz S, Matos JM, Doyle C, et al. Ethanol-TGFalpha-MEK signaling promotes growth of human hepatocellular carcinoma. J Surg Res. 2009;154(2):187-95.

19. Huang CS, Ho CT, Tu SH, Pan MH, Chuang CH, Chang HW, et al. Long-term ethanol exposure-induced hepatocellular carcinoma cell migration and invasion through lysyl oxidase activation are attenuated by combined treatment with pterostilbene and curcumin analogues. J Agric Food Chem. 2013;61(18):4326-35.

20. Brandon-Warner E, Walling TL, Schrum LW, McKillop IH. Chronic ethanol feeding accelerates hepatocellular carcinoma progression in a sexdependent manner in a mouse model of hepatocarcinogenesis. Alcohol Clin Exp Res. 2012;36(4):641-53.
21. Donato F, Tagger A, Chiesa R, Ribero ML, Tomasoni V, Fasola M, et al. Hepatitis B and C virus infection, alcohol drinking and hepatocellular carcinoma: a case-control study in Italy. Hepatology. 1997;26(3):579-84.

22. Berasain C, Castillo J, Perugorria MJ, Latasa MU, Prieto J, Avila MA. Inflammation and liver cancer: new molecular links. Ann NY Acad Sci. 2009;1155:206-21.

23. Reddy A, May E, Ehrinpreis M, Mutchnick M. Latent hepatitis B is a risk factor for hepatocellular carcinoma in patients with chronic hepatitis C. World J Gastroenterol. 2013;19(48):9328-33.

24. Leonardi GC, Candido S, Cervello M, Nicolosi D, Raiti F, Travali S, et al. The tumor microenvironment in hepatocellular carcinoma (review). Int J Oncol. 2012;40(6):1733-47.

25. Tan W, Bailey AP, Shparago M, Busby B, Covington J, Johnson JW, et al. Chronic alcohol consumption stimulates VEGF expression, tumor angiogenesis and progression of melanoma in mice. Cancer Biol Ther. 2007;6(8):1211-7.

26. Wang L, Son YO, Ding S, Wang $X$, Hitron JA, Budhraja A, et al. Ethanol enhances tumor angiogenesis in vitro induced by low-dose arsenic in colon cancer cells through hypoxia-inducible factor 1 alpha pathway. Toxicol Sci. 2012;130(2):269-80.

27. Le Guelte A, Dwyer J, Gavard J. Jumping the barrier: VE-cadherin, VEGF and other angiogenic modifiers in cancer. Biol Cell. 2011;103(12):593-605.

28. Soria G, Ben-Baruch A. The inflammatory chemokines CCL2 and CCL5 in breast cancer. Cancer Lett. 2008;267(2):271-85.

29. Jia JB, Zhuang PY, Sun HC, Zhang JB, Zhang W, Zhu XD, et al. Protein expression profiling of vascular endothelial growth factor and its receptors identifies subclasses of hepatocellular carcinoma and predicts survival. J Cancer Res Clin Oncol. 2009;135(6):847-54.

30. Silva SR, Bowen KA, Rychahou PG, Jackson LN, Weiss HL, Lee EY, et al. VEGFR-2 expression in carcinoid cancer cells and its role in tumor growth and metastasis. Int J Cancer. 2011;128(5):1045-56.

31. Deli $G$, Jin $C H$, Mu R, Yang S, Liang Y, Chen D, et al. Immunohistochemical assessment of angiogenesis in hepatocellular carcinoma and surrounding cirrhotic liver tissues. World J Gastroenterol. 2005;11(7):960-3.

32. Izhak L, Wildbaum G, Jung S, Stein A, Shaked Y, Karin N. Dissecting the autocrine and paracrine roles of the CCR2-CCL2 axis in tumor survival and angiogenesis. PLoS One. 2012;7(1):e28305.

33. Zhang J, Lu Y, Pienta KJ. Multiple roles of chemokine (C-C motif) ligand 2 in promoting prostate cancer growth. J Natl Cancer Inst. 2010;102(8):522-8.

34. Kuroda T, Kitadai Y, Tanaka S, Yang X, Mukaida N, Yoshihara M, et al. Monocyte chemoattractant protein-1 transfection induces angiogenesis and tumorigenesis of gastric carcinoma in nude mice via macrophage recruitment. Clin Cancer Res. 2005;11(21):7629-36.

35. Naugler WE, Karin M. NF-kappaB and cancer-identifying targets and mechanisms. Curr Opin Genet Dev. 2008;18(1):19-26.

36. Pelucchi C, Tramacere I, Boffetta P, Negri E, La Vecchia C. Alcohol consumption and cancer risk. Nutr Cancer. 2011;63(7):983-90.

37. Ma C, Lin H, Leonard SS, Shi X, Ye J, Luo J. Overexpression of ErbB2 enhances ethanol-stimulated intracellular signaling and invasion of human mammary epithelial and breast cancer cells in vitro. Oncogene. 2003;22 (34):5281-90.

38. Xu M, Bower KA, Wang S, Frank JA, Chen G, Ding M, et al. Cyanidin-3-glucoside inhibits ethanol-induced invasion of breast cancer cells overexpressing ErbB2. Mol Cancer. 2010;9:285-93.

39. Gloire G, Legrand-Poels S, Piette J. NF-kappaB activation by reactive oxygen species: fifteen years later. Biochem Pharmacol. 2006;72(11):1493-505.

40. Bordenave L, Baquey C, Bareille R, Lefebvre F, Lauroua C, Guerin V, et al. Endothelial cell compatibility testing of three different pellethanes. J Biomed Mater Res. 1993;27(11):1367-81.

41. Ke Z, Wang X, Liu Y, Fan Z, Chen G, Xu M, et al. Ethanol induces endoplasmic reticulum stress in the developing brain. Alcohol Clin Exp Res. 2011;35(9):1574-83.

42. Gibellini L, Pinti M, Nasi M, De Biasi S, Roat E, Bertoncelli L, et al. Interfering with ROS metabolism in cancer cells: the potential role of quercetin. Cancers. 2010;2(2):1288-311.

43. Liu Y, Chen G, Ma C, Bower KA, Xu M, Fan Z, et al. Overexpression of glycogen synthase kinase 3 beta sensitizes neuronal cells to ethanol toxicity. J Neurosci Res. 2009;87(12):2793-802.

44. Hlatky L, Hahnfeldt P, Folkman J. Clinical application of antiangiogenic therapy: microvessel density, what it does and doesn't tell us. J Natl Cancer Inst. 2002;94(12):883-93. 
45. Chen G, Bower KA, Xu M, Ding M, Shi X, Ke ZJ, et al. Cyanidin-3-glucoside reverses ethanol-induced inhibition of neurite outgrowth: role of glycogen synthase kinase 3 Beta. Neurotox Res. 2009;15(4):321-31.

46. Ding M, Feng R, Wang SY, Bowman L, Lu Y, Qian Y, et al.

Cyanidin-3-glucoside, a natural product derived from blackberry,

exhibits chemopreventive and chemotherapeutic activity. J Biol Chem. 2006;281 (25):17359-68.

47. Lai JP, Chien J, Strome SE, Staub J, Montoya DP, Greene EL, et al. HSulf-1 modulates HGF-mediated tumor cell invasion and signaling in head and neck squamous carcinoma. Oncogene. 2004;23(7):1439-47.

\section{Submit your next manuscript to BioMed Central} and take full advantage of:

- Convenient online submission

- Thorough peer review

- No space constraints or color figure charges

- Immediate publication on acceptance

- Inclusion in PubMed, CAS, Scopus and Google Scholar

- Research which is freely available for redistribution 